\title{
Extended-spectrum $\beta$-lactamase (ESBL)-producing enterobacteria isolated from broiler breeder chickens
}

\author{
Taniara Suelen Mezalira ${ }^{1}$ \\ Daniela Dib Gonçalves ${ }^{1}$ \\ Eduardo Herrera Dias ${ }^{1}$ \\ Fábio Mendes da Silva ${ }^{2}$ \\ Isabela Carvalho dos Santos ${ }^{1}$ \\ Edson Gerônimo ${ }^{1}$ \\ Jaciele Caroline Pereira Dias ${ }^{1}$ \\ Luciana Kazue Otutumi ${ }^{1}$ * \\ ${ }^{1}$ Universidade Paranaense - Curso de Medicina Veterinária e \\ Programa de Pós-graduação em Ciência Animal - Ênfase em Produtos Bioativos \\ Praça Mascarenha de Moraes, 4.282, Centro, CEP 87.502-210, Umuarama - PR, Brazil \\ ${ }^{2}$ Engenheiro Agrônomo pelo Centro Universitário Fundação Assis Gurgacz, Cascavel - PR, Brazil \\ * Autor para correspondência \\ otutumi@prof.unipar.br
}

Submetido em 17/03/2019

Aceito para publicação em 16/10/2019

\section{Resumo}

Enterobactérias produtoras de $\beta$-lactamases de espectro estendido (ESBL) isoladas de matrizes de frangos de corte. Devido ao uso de antibióticos para o tratamento e prevenção de infecções bacterianas durante a produção de matrizes pesadas, torna-se importante estudar o perfil de resistência e a prevalência de bactérias gram-negativas produtoras de ESBL. Dentre as várias classes de antibióticos disponíveis, destacam-se os agentes beta-lactâmicos, categoria antimicrobiana amplamente utilizada em clínica médica humana e veterinária. Assim, este trabalho teve como objetivo avaliar o perfil de resistência e caracterizar as cepas produtoras de beta-lactamases de espectro estendido (ESBL) isoladas de matrizes de corte por meio da coleta de 87 swabs cloacais. As bactérias Gram-negativas foram isoladas em meios seletivos, identificadas por métodos bioquímicos convencionais e MALDI-TOF® e estudadas quanto à resistência antimicrobiana, incluindo ESBL. Das 87 amostras, foram isoladas 52 bactérias gram-negativas. Houve alta resistência bacteriana às principais classes de antibióticos utilizados em aves: penicilinas, cefalosporinas e quinolonas. Também foi encontrado fenótipo sugestivo de produção de ESBL em 42,31\% dos isolados, demonstrando resistência aos antibióticos beta-lactâmicos testados. Os resultados demonstram a necessidade de orientação dos profissionais que trabalham com matrizes de corte, a fim de se reduzir a presença de bactérias resistentes e produtoras de ESBL e evitar sua disseminação para o meio ambiente, ovos férteis e frangos de corte e, consequentemente, carne de frango e humanos.

Palavras-chave: Antibiograma; Beta-lactâmicos; Swab cloacal 


\section{Abstract}

Due to the use of antibiotics for the treatment and prevention of bacterial infections in intensive poultry production, it is important to study the prevalence and resistance profile of gram-negative extended-spectrum beta-lactamase (ESBL)-producing bacteria. Among the several classes of antibiotics available, beta-lactam agents are the most widely used category in human and veterinary medicine. Thus, the objective of this work was to evaluate the resistance profile and ESBL-producing capacity of strains isolated from broiler breeders. Gram-negative bacteria were isolated in selective media from a collection of 87 cloacal swabs, and they were identified by conventional biochemical methods and MALDI-TOF mass spectrometry and studied for antibiotic resistance, including ESBL production. Of the 87 samples, 52 gram-negative bacteria were isolated. There was high bacterial resistance to the main classes of antibiotics used in poultry: cephalosporins (74.2\%), quinolones (73.8\%) and penicillins (73.6\%). A phenotype suggestive of ESBL production was also found in $42.31 \%$ of isolates, showing resistance to the beta-lactam antibiotics tested. The results demonstrate the need for the guidance of professionals working broiler breeders to reduce the presence of drug-resistant and ESBLproducing bacteria and to prevent their spread to the environment, fertile eggs and broilers, and consequently to chicken meat and humans.

Key words: Antibiogram; Beta-lactams; Cloacal swab

\section{Introduction}

Brazil is the world's largest exporter and one of the largest producers of chicken meat, behind only the United States according to the Brazilian Association of Animal Protein (ABPA, 2018).

To meet this demand in terms of quality and quantity, several factors are involved, such as breeding lines and inputs, investments in automation technology, control of sanitary breeding conditions, improving the management of broiler chickens, and also the integrated production system (BRASIL, 2012). However, this chain is very competitive and has challenging health conditions, mainly targeting sales in the foreign market.

The presence of members of the order Enterobacteriales in poultry production is of great importance, since birds are epidemiologically the animal species most affected by various enteric species, such as salmonella, which are bacteria that are difficult to control. Enteric microorganisms then become continuously present in the environment, and this thereby leads to contamination of the supply of animal products, where these bacterial contaminants can be transmitted to humans (BORSOI et al., 2010). In addition, other Enterobacteriales species stand out as being responsible for many hospital infections (urinary tract infections and sepsis, among others) and intestinal infections in humans in many countries (KAPER et al., 2004; EWERS et al., 2010).

Antibiotics are used to treat these bacterial infections, and their routine use is an important issue in livestock production due to the possibility of the development and spread of bacterial resistance, which can be transmitted to humans via the food chain (MION et al., 2014).

In food-producing animals, wide-spectrum antibiotics have been widely used as growth promoters, in the treatment of diseased animals and for prophylactic purposes as well (CARATTOLI, 2008; TROTT, 2013), causing commensal bacteria such as Escherichia coli, colonizing the gastrointestinal tract of most animals and humans, to exert a positive selective pressure on the bacteria that carry antibiotic resistance-encoding genes and/or genes encoding virulence factors (COSTA, 2011).

The drug-resistant bacteria occurring more in food production lines include the extended-spectrum betalactamase (ESBL)-producing bacteria. Gram-negative ESBL-producing bacteria have become a common problem in veterinary medicine around the world (SANTOS et al., 2013).

Among the many available drug classes, the beta-lactam agents are an antibiotic category widely used in human and veterinary medicine, including penicillins, carbapenems, monobactams (aztreonam) 
and cephalosporins. This class is more commonly used in veterinary medicine (MINARINI et al., 2007), where the main resistance mechanism associated with these antibiotics is the production of beta-lactamase (SILVA; LINCOPAN, 2012).

ESBL-producing bacteria in poultry were first reported in fecal samples of healthy and sick birds (BRIÑAS et al., 2003). In Brazil, Fernandes et al. (2016) characterized ESBL enzymes among Salmonella strains isolated from poultry meat and Ziech et al. (2016) from Salmonella spp. isolated from conveyor belts of cutting rooms in broiler processing plants.

Thus, the objective of this study was to determine the resistance profile and ESBL-producing capacity of Enterobacterales species isolated from cloacal swabs from broiler breeder farms located in west Parana State, Brazil.

\section{Material and Methods}

The methods were evaluated and approved by the Ethics Committee in Animal Experimentation of Paranaense University under protocol number 28346/2014.

\section{Population and study location}

Samples of 87 poultry (Gallus gallus) were harvested from two broiler breeder farms located in west Parana State in the period of September to December 2014. The number of samples obtained per farm and the age of the animals are shown in Table 1.

After the accommodation of the birds in both farms, on the first day of life, the birds were preventively treated with enrofloxacin at a dose of $10 \mathrm{mg} / \mathrm{kg}$ for five days. Moreover, the birds in farm 2 were medicated again at 12 weeks with $15 \mathrm{mg} / \mathrm{kg}$ norfloxacin for seven days, since they showed signs of non-specific enteritis which was resulting in a lower weight gain.

\section{Collection of samples}

Sampling was carried out by cloacal swab. After collection, the swab was kept in the transport medium (Stuart) for processing in the Laboratory of Preventive Veterinary Medicine and Public Health at Universidade Paranaense (UNIPAR).

\section{Laboratory techniques Isolation and identification of bacterial strains}

The swabs were forwarded to the Laboratory of Preventive Veterinary Medicine and Public Health at UNIPAR. Tubes containing $3.0 \mathrm{~mL}$ of brain heart infusion (BHI) medium were inoculated with the swabs and kept in a microbiological incubator for 24 hours at $37^{\circ} \mathrm{C}$.

The cultures obtained were streaked on plates containing MacConkey agar with cefotaxime $(10 \mu \mathrm{g} / \mathrm{mL})$ and kept in a microbiological incubator at $37^{\circ} \mathrm{C}$ for 24 hours for isolation of cephalosporin-resistant colonies indicative of ESBL production. Approximately ten colonies from each plate were selected for further analyses. For their preservation, they were replicated in BHI medium and stored in $80 \%$ glycerol at $-20^{\circ} \mathrm{C}$.

All isolates were identified using Enterokit Newprov ${ }^{\circledR}$ and then confirmed using matrix-assisted laser desorption ionization-time of flight mass spectrometry (MALDI-TOF) at Laboratory Fleury, São Paulo.

TABLE 1: Number of samples obtained per broiler breeders sheds and age of animals.

\begin{tabular}{cccc}
\hline Farms & Sheds & Age weeks & Number of samples \\
\hline 1 & $\begin{array}{c}\text { Three sheds with 12,800 females each } \\
\text { One shed with 5,650 males }\end{array}$ & 6 & 26 \\
2 & $\begin{array}{c}\text { Three sheds with 12,000 females each } \\
\text { One shed with 4,645 males }\end{array}$ & 20 & 36 \\
\hline & $\begin{array}{c}\text { Three sheds with 12,000 females each } \\
\text { One shed with 4,645 males }\end{array}$ & 26 & 35 \\
\hline
\end{tabular}




\section{Phenotypic assays for antibiotic sensitivity}

Screening assays were performed to identify the strains resistant to any antibiotic class. The previously described agar disk-diffusion method was used, according to the recommendations from the Clinical and Laboratory Standards Institute (BAUER et al., 1966; CLSI, 2018). The disks tested were: gentamicin (GEN), ciprofloxacin (CIP), ceftazidin (CAZ), sulfazotrim (SUT), amikacin (AMI), aztreonam (ATM), chloramphenicol (CLO), ampicillin (AMP), tobramycin (TOB), cefoxitin (CFO), ceftriaxone (CRO) cefotaxime (CTX), tetracycline (TET), amoxicillin (AMO) and amoxicillin + clavulanate (AMC), imipenem (IMP), meropenem (MER) and nalidixic acid (NAL). Since the samples were isolated from animals, enrofloxacin (ENO) and ceftiofur (CTF), antibiotics exclusively used in veterinary medicine, were also tested.

\section{Determination of Multiple Antibiotic Resistance}

The bacterial isolates were classified according to their multidrug resistance (MDR) profile as described by Sweeney et al. (2018), or as not being susceptible to at least one agent in at least three antibiotic classes.

\section{Phenotypic characterization of ESBL- production}

Phenotypic confirmation of ESBL production was performed by the double-disk synergy test, where disks containing cefotaxime (CTX), ceftazidime (CAZ) and aztreonam (ATM) were placed $20 \mathrm{~mm}$ from a disk containing amoxicillin/clavulanic acid $(20 / 10 \mu \mathrm{g})$. Any increase/distortion (ghost zone) in the inhibition zone of one of the antibiotics towards the amoxicillin + clavulanic acid disk was considered suggestive of ESBL production (BRUN-BUISSON et al., 1987).

\section{Statistical analyses}

The data were analyzed in the statistics program IBM SPSS v. 21.0. The antibiotic-resistance profile was compared in relation to two species isolated by Fisher's exact test. A significance level of 5\% was used for all tests. Bacteria with an ESBL profile were identified and the results were tabulated in relation to the antibiotics for which the sample was resistant, and sex and age of the animal of origin.

\section{Results}

Of 87 samples examined, 49 strains were isolated, where $83.7 \%(41 / 49)$ were E. coli and $16.3 \%(8 / 49)$ Proteus mirabilis. The results showed that there was a high percentage of drug resistance to cephalosporins (74.2\%), quinolones $(73.8 \%)$ and penicillins $(73.6 \%)$ (Table 2). There were significant differences $(\mathrm{P}<0.05)$ between the isolated species in their resistance profile for the antibiotics ceftazidime $(\mathrm{P}=0.010)$ and aztreonam $(\mathrm{P}=0.039)$ (Table 2).

All samples (100\%) exhibited MDR, according to the criteria described by Sweeney et al. (2018). With respect the phenotypic detection of ESBLs, among the 49 isolates, 22 (44.9\%) displayed the ESBL resistance phenotype, characterized by the presence of a ghost zone, confirming $\beta$-lactamase production in disk diffusion susceptibility testing (Table 3 ).

Regarding the phenotypic distribution (presence of ghost zone) and comparing the ages of the collected samples, we found that $14 / 22$ samples were obtained from six-week-old broiler breeders, $2 / 22$ at 20 weeks of age and $6 / 22$ at 26 weeks of age (Table 3). All 22 isolates showed resistance to at least three of the antibiotics tested in the cephalosporin class, and $100 \%$ of the isolates were resistant to ampicillin and amoxicillin. 
TABLE 2: Number and percentage of antibiotic-resistant isolates among 49 isolates (41 Escherichia coli and 8 Proteus mirabilis) from broiler breeders in western Paraná State, 2014.

\begin{tabular}{|c|c|c|c|c|c|}
\hline \multirow{2}{*}{ Class } & \multirow{2}{*}{ Antibiotic } & \multicolumn{2}{|c|}{$\begin{array}{c}\text { Resistance profile } \\
(\mathrm{n}, \%)\end{array}$} & \multirow{2}{*}{ Mean \% } & \multirow{2}{*}{ P value* } \\
\hline & & $\begin{array}{l}\text { E. coli } \\
n=41\end{array}$ & $\begin{array}{c}\text { P. mirabilis } \\
n=8\end{array}$ & & \\
\hline \multirow{4}{*}{ Quinolones } & Norfloxacin (NOR) & $22(53.7 \%)$ & $6(75 \%)$ & \multirow{4}{*}{73.8} & 0.438 \\
\hline & Enrofloxacin (ENO) & $25(61.0 \%)$ & $6(75 \%)$ & & 0.693 \\
\hline & Nalidixic acid (NAL) & $38(92.7 \%)$ & $8(100 \%)$ & & 1.000 \\
\hline & Ciprofloxacin (CIP) & $24(58.5 \%)$ & $6(75 \%)$ & & 0.458 \\
\hline \multirow{3}{*}{ Aminoglycosides } & Tobramicin (TOB) & $2(4.9 \%)$ & $0(0 \%)$ & \multirow{3}{*}{2.8} & 1.000 \\
\hline & Amikacin (AMI) & $0(0 \%)$ & $0(0 \%)$ & & --- \\
\hline & Gentamicin (GEN) & $5(12.2 \%)$ & $0(0 \%)$ & & 0.575 \\
\hline \multirow{2}{*}{ Carbapenemes } & Meropenem (MER) & $0(0 \%)$ & $0(0 \%)$ & \multirow{2}{*}{0.0} & --- \\
\hline & Imipenem (IPM) & $0(0 \%)$ & $0(0 \%)$ & & --- \\
\hline \multirow{5}{*}{ Cephalosporins } & Ceftazidime (CAZ) & $31(75.6 \%)$ & $2(25 \%)$ & \multirow{5}{*}{74.2} & 0.010 \\
\hline & Ceftriaxone (CRO) & $40(97.6 \%)$ & $7(87.5 \%)$ & & 0.303 \\
\hline & Cefotaxime (CTX) & $39(95.1 \%)$ & $7(87.5 \%)$ & & 0.421 \\
\hline & Ceftiofur (CTF) & $34(82.9 \%)$ & $5(62.5 \%)$ & & 0.333 \\
\hline & Cefoxitin (CFO) & $32(78.0 \%)$ & $4(50 \%)$ & & 0.183 \\
\hline \multirow{3}{*}{ Penicillins } & Ampicillin (AMP) & $40(97.6 \%)$ & $7(87.5 \%)$ & \multirow{3}{*}{73.6} & 0.303 \\
\hline & Amoxicillin (AMO) & $40(97.6 \%)$ & $7(87.5 \%)$ & & 0.303 \\
\hline & $\begin{array}{l}\text { Amox.+ Clavulanate } \\
(\mathrm{AMC})\end{array}$ & $19(46.3 \%)$ & $2(25 \%)$ & & 0.438 \\
\hline
\end{tabular}

TABLE 3: Identification and characterization of 22 ESBL producers isolated from 49 isolated strains from broiler breeders at two farms in western Paraná State, 2014.

\begin{tabular}{|c|c|c|c|c|}
\hline Sample & Age (weeks) & Sex & Species & ATB resistance \\
\hline 86 & 6 & $\mathrm{M}$ & E. coli & CAZ, CRO, CTX, CTF, CFO, AMP, AMO \\
\hline 87 & 6 & M & E. coli & CAZ, CRO, CTX, CTF, CFO, AMP, AMO \\
\hline 88 & 6 & M & E. coli & CAZ, CRO, CTX, CTF, CFO, AMP, AMO \\
\hline 89 & 6 & M & E. coli & CAZ, CRO, CTX, CTF, CFO, AMP, AMO \\
\hline 90 & 6 & M & E. coli & CAZ, CRO, CTX, CTF, CFO, AMP, AMO \\
\hline 97 & 6 & $\mathrm{~F}$ & E. coli & CAZ, CRO, CTX, CTF, CFO, AMP, AMO \\
\hline 99 & 6 & $\mathrm{~F}$ & E. coli & CAZ, CRO, CTX, CTF, CFO, AMP, AMO \\
\hline 100 & 6 & $\mathrm{~F}$ & E. coli & CAZ, CRO, CTX, CTF, CFO, AMP, AMO \\
\hline 106 & 6 & $\mathrm{~F}$ & E. coli & CAZ, CRO, CTX, CTF, CFO, AMP, AMO \\
\hline 107 & 6 & $\mathrm{~F}$ & E. coli & CAZ, CRO, CTX, CTF, CFO, AMP, AMO \\
\hline 108 & 6 & $\mathrm{~F}$ & E. coli & CAZ, CRO, CTX, CTF, CFO, AMP, AMO \\
\hline 109 & 6 & $\mathrm{~F}$ & E. coli & CAZ, CRO, CTX, CTF, CFO, AMP, AMO \\
\hline 110 & 6 & $\mathrm{~F}$ & E. coli & CAZ, CRO, CTX, CTF, CFO, AMP, AMO \\
\hline 111 & 6 & $\mathrm{~F}$ & E. coli & CAZ, CRO, CTX, CTF, CFO, AMP, AMO \\
\hline 73 & 20 & $\mathrm{~F}$ & E. coli & CAZ, CRO, CTX, CTF, CFO, AMP, AMO \\
\hline 80 & 20 & $\mathrm{~F}$ & E. coli & CRO, CTX, CTF, CFO, AMP, AMO \\
\hline
\end{tabular}




$\begin{array}{llllc}112 & 26 & \text { F } & \text { E. coli } & \text { CRO, CTX, CTF, AMP, AMO } \\ 113 & 26 & \text { F } & \text { P. mirabilis } & \text { CRO, CTX, CTF, AMP, AMO } \\ 117 & 26 & \text { F } & \text { E. coli } & \text { CRO, CTX, CTF, AMP, AMO } \\ 122 & 26 & \text { F } & \text { P. mirabilis } & \text { CRO, CTX, CTF, CFO, AMP, AMO } \\ 123 & 26 & \text { F } & \text { E. coli } & \text { CRO, CTX, CTF, AMP, AMO }\end{array}$

M: Male; F: Female. ATB: antibiotic; CAZ: ceftazidime; CRO: ceftriaxone; CTX: cefotaxime; CTF: ceftiofur; CFO: cefoxitin; AMP: ampicillin; AMO: amoxicillin.

\section{Discussion}

The low diversity of Enterobacteriales in the samples evaluated was due to the fact that only the predominant microorganism was selected in the isolates present in MacConkey agar. The isolates of E. coli and P. mirabilis from cloacal swab samples from broilers showed a high resistance profile mainly with regard to cephalosporins, quinolones and penicillins (Table 2). This high resistance profile demonstrates a unique health problem, since it is possible for these resistant microorganisms to remain in the breeding environment and to contaminate both eggs and egg handlers and to spread the contamination to the hatchery, and as a consequence, broiler chicks and chicken meat would be contaminated as well.

Van den Bogaard and Stobberingh (2000) pointed out that resistant commensal bacteria of food animals could contaminate meat products, such as zoonotic bacteria, and then reach the intestinal tract of humans, demonstrating their importance in terms of public health.

Specifically, in relation to the antibiotics ampicillin, ciprofloxacin and cefotaxime, Chantziaras et al. (2013) reported a high prevalence of drug resistance in samples of $E$. coli isolated from broilers in European countries. Similarly, in the present study, 97.6, 58.5 and $95.1 \%$ of E. coli isolates were resistant to ampicillin, ciprofloxacin and cefotaxime, respectively.

In the work carried out by Cardoso et al. (2002), the percentage of $E$. coli strains isolated from broiler breeders testing drug resistant for amoxicillin and norfloxacin was 60 and $50 \%$, respectively. This result is slightly below that found for the antibiotic amoxicillin (97.6\%) (Table 2).

Mion et al. (2014) evaluated the antibiotic resistance profile of Salmonella Heidelberg isolated from a poultry slaughterhouse in 2009 and also found $100 \%$ resistance to antibiotics of the cephalosporin class (cephalothin, cephalexin and ceftiofur) and ampicillin. However, in 2005, they reported on the resistance profile in the same slaughterhouse and found that resistance to cephalosporins and ampicillin was only 61.3 and 23\% respectively, clearly indicating that there was an increase in drug resistance for these antibiotic classes (penicillins and cephalosporins) over time.

Bortolaia et al. (2010) showed resistance in $E$. coli isolates from healthy broilers at Italian farms to nalidixic acid in $83 \%$ and to ciprofloxacin in $44 \%$. It should be noted that in this Italian study, the resistance profile was determined in broiler breeders between six and 26 weeks of age. The results of the resistance profile for these quinolone antibiotics (nalidixic acid and ciprofloxacin) resemble those found in the present study, where the highest percentage was for nalidixic acid $(92.7 \%)$, followed by enrofloxacin $(61 \%)$ and ciprofloxacin (58.5\%) (Table 2).

Regarding the results of the resistance profile for tetracycline (E. coli $-80.5 \%$ and P. mirabilis $-75 \%)$ (Table 2), it is worth noting that $P$. mirabilis shows intrinsic resistance to this antibiotic (EUCAST, 2016); that is, they have structural or enzymatic characteristics that confer resistance to a given antibiotic (BAPTISTA, 2013).

Campos et al. (2013) also found a high level of tetracycline resistance $(90.5 \%)$, but the isolated microorganism was Enterococcus faecalis from a refrigerated chicken carcass. However, Fracalanzza et al. (2007) reported tetracycline resistance in the same bacterial species in only $31.2 \%$ of chicken carcasses.

The use of tetracycline in chicken feed as a growth promoter was banned in Brazil in 2009 by the Ministry 
of Agriculture, Livestock and Supply (BRASIL, 2009). Furthermore, according to Busani et al. (2004), Kaszanyitzky et al. (2007) and Zou et al. (2011), it is difficult to assess the resistance to tetracycline induced by animal therapy, since this antibiotic has been used for decades in animal and human therapy reflecting the high prevalence of resistance to tetracycline and often erythromycin in animal husbandry. This may be related to the fact that the intestinal microbiota of animals has become resistant to tetracyclines.

Brower et al. (2017) evaluated E. coli isolates from poultry farms in India and found an increased prevalence of MDR, namely $94 \%$ in broilers and $60 \%$ in layers.

The high percentage of samples with the ESBL phenotypic profile found at six weeks $(14 / 26,53.85 \%)$ (Table 3 ) indicates that other factors probably related to the environment may contribute to the high prevalence of drug resistance and the ESBL-producing phenotype, demonstrating the need for caution related to antibiotic therapy and prophylaxis, especially the use of antibiotics as a growth promoter. However, finding some samples with the ESBL phenotypic profile at 20 weeks $(2 / 26$, $7.69 \%)$ and 26 weeks $(6 / 35,17.14 \%)$ can also be related to the permanence of isolates resistant to quinolones in animals, since the animals were treated for nonspecific enteritis with the antibiotic norfloxacin, a quinolone. This demonstrates the need for other genotypic studies aimed at identifying genes related to quinolone resistance in these strains.

Similar results were reported by Costa (2011), who evaluated antibiotic resistance in ESBL-producing $E$. coli isolates from broiler samples intended for human consumption. In this cited study, 27 isolates were from wings, breasts, thighs, skin and gizzards, of which 23 (85.2\%) were positive for phenotypic detection of ESBL, and all were resistant to ampicillin, 17 to tetracycline, and 11 to cefotaxime.

Studies evaluating antibiotic-resistance profile in samples from broiler breeders have been conducted in Australia (GINNS et al., 1996), Brazil (RIBEIRO et al., 2008), Portugal (CLEMENTE et al., 2014) and Italy (PASQUALI et al., 2015). Thus, our work is important in providing data related to antibiotic resistance profile of isolates of the order Enterobacterales derived from broiler breeders, as it may predispose to the transmission of resistance to chicks and consequently chickens, explained by the presence of resistant strains in broiler carcasses (FRACALANZZA et al., 2007; DUARTE et al., 2009; COSTA, 2011; CAMPOS et al., 2013).

Silva and Lincopan (2012) report that ESBLs are encoded by genes present in mobile genetic elements, such as plasmids, transposons and integrons, which also carry resistance genes for other antibiotic classes (other than cephalosporins), demonstrating that the presence of multiresistant ESBL-producing bacteria is one of the main causes of therapeutic failure.

Thus, ESBL-producing gram-negative bacteria have become a common problem in veterinary medicine around the world, and ESBL production has been detected in different species of enterobacteria such as Klebsiella pneumoniae, K. oxytoca, E. coli, P. mirabilis, Enterobacter cloacae, Morganella morganii, Serratia spp., Shigella spp., Citrobacter spp., and Salmonella species (SANTOS et al., 2013).

With regard to broiler chickens, ESBL-producing Enterobacterales have been detected in an avian environment (GELINSK et al., 2014), cloacal swabs (GIRLICH et al., 2007; FERREIRA et al., 2014; CASELLA et al., 2015; LIM et al., 2015; BELMAHDI et al., 2016), chicken carcasses (KOGA et al., 2015; LIM et al., 2015), and broiler processing plants (ZIECH et al., 2016).

Dierikx et al. (2013) found the presence of ESBLproducing $E$. coli along the chicken production chain from breeding to production of broilers, even after cleaning and disinfection of poultry houses and concluded that measures should be taken to minimize contamination of broilers both horizontally and vertically.

E. coli infections occur in the daily routine of those who work with farm animals (CUNHA et al., 2013), and the fact that studies have demonstrated that strains of avian origin can cause infections in experimental mammalian models, strengthens the thesis of a zoonotic potential (TIVENDALE et al., 2004; MOULINSCHOULER et al., 2007) in the contact of humans with birds. 
Van den Bogaard et al. (2011) emphasize that resistant bacteria derived from animals, among zoonotic bacteria or the intestinal microbiota, can infect or reach the human population by direct contact and via animal products, which can colonize humans and/or transfer their resistance genes to other bacteria of the endogenous microbiota of humans.

In conclusion, microorganisms from the order Enterobacterales isolated from broilers exhibit MDR involving the main classes of antibiotics (cephalosporins, quinolones and penicillins) and ESBL-producing strains, demonstrating the need for guidance of professionals who work directly or indirectly with broiler breeders, to reduce the presence of multidrug-resistant bacteria and ESBL producers and to avoid their dissemination in the environment and among fertile eggs and broiler chicks, aimed at preventing the emergence of multidrug-resistant bacteria in chicken meat and consequent infections in humans.

\section{Acknowledgements}

The authors would like to thank UNIPAR for funding this research.

\section{References}

ABPA - ASSOCIAÇÃO BRASILEIRA DE PROTEÍNA ANIMAL. Relatório Anual 2018. 2018. Disponível em: $<$ http://abpa-br.com. br/storage/files/relatorio-anual-2018.pdf $>$.

BAPTISTA, M. G. F. M. Mecanismos de resistência aos antibióticos. 2013. 51 f. Dissertação (Mestrado em Ciências Farmacêuticas) - Universidade Lusófona de Humanidades e Tecnologia, Lisboa. 2013.

BAUER, A. W.; KIRBY, W. M. M.; SHERRIS, J. C.; TURCK, M. Antibiotic susceptibility testing by a standardized single disk method. American Journal of Clinical Pathology, New York, v. 45, n. 4, p. 493-496, 1966.

BELMAHDI, M.; BAKOUR, S.; BAYSSARI, C. A.; TOUATI, A.; ROLAIN, J. Molecular characterization of extended-spectrum $\beta$-lactamase and plasmid AmpC-producing Escherichia coli strains isolated from broilers in Béjaïa, Algeria. Journal of Global Antimicrobial Resistance, Catania, v. 6, p. 108-112, 2016.

BORSOI, A.; MORAES, H. L. S.; SALLE, C. T. P.; NASCIMENTO, V. P. Número mais provável de Salmonella isoladas de carcaças de frango resfriadas. Revista Ciência Rural, Santa Maria, v. 40, n. 11, p. 2338-2342, 2010.
BORTOLAIA, V.; GUARDABASSI, L.; TREVISANI, M.; BISGAARD, M.; VENTURI, L.; BOJESEN, A. M.. High diversity of extended-spectrum betalactamases in Escherichia coli isolates from Italian broiler flocks. Antimicrobial Agents and Chemotherapy, Washington, v. 54, n. 4, p. 1623-1626, 2010.

BRASIL - MINISTÉRIO DA AGRICULTURA PECUÁRIA E ABASTECIMENTO. Instrução Normativa no 26 de 9/07/2009. 2009. Disponível em: <www.agricultura.gov.br $\geq$.

BRASIL - MINISTÉRIO DA AGRICULTURA PECUÁRIA E ABASTECIMENTO. Brasil: Projeções do Agronegócio 2011/12 a 2021/22. 2012. Disponível em: <www.agricultura.gov.br>.

BRIÑAS, L.; MORENO, M. A.; ZARAZAGA, M.; PORRERO, C.; SÁENZ, Y.; GARCIA, M.; DOMINGUEZ, L.; TORRES, C. Detection of CMY-2, CTX-M-14, and SHV-12 beta-lactamases in Escherichia coli fecal sample isolates from healthy chickens. Antimicrobial Agents and Chemotherapy, Washington, v. 47, n. 6, p. 2056-2058, 2003.

BROWER, C. H.; MANDAL, S.; HAYER, S.; SRAN, M.; ZEHRA, A.; PATEL, S. J.; KAUR, R.; CHATTERJEE, L.; MISHRA, S.; DAS, B. R.; SINGH, P.; GILL, J. P. S.; LAXMINARAYAN, R. The prevalence of extended-spectrum beta-lactamase-producing multidrug-resistant Escherichia coli in poultry chickens and variation according to farming practices in Punjab, India. Environmental Health Perspectives, Weston Parkway Cary, v. 125, n. 7, p. 1-10, 2017.

BRUN-BUISSON, C.; PHILIPPON, A.; ANSQUER, M.; LEGRAND, P.; MONTRAVERS, F.; DUVAL, J. Transferable enzymatic resistance to third-generation cephalosporins during nosocomial outbreak of multiresistant Klebsiella pneumoniae. The Lancet, London, v. 8554, p. 302-306, 1987.

BUSANI, L.; DEL GROSSO, M.; PALADINI, C.; GRAZIANI, C.; PANTOSTI, A.; BIAVASCO, F.; CAPRIOLI, A. Antimicrobial susceptibility of vancomycin-susceptible and - resistant enterococci isolated in Italy from raw meat products, farm animals, and human infections. International Journal of Food Microbiology, SummitArgo, v. 97, p. 17-22, 2004.

CAMPOS, A. C. F. B.; SOUZA, N. R.; DA SILVA, P. H.; SANTANA, Â. P. Resistência antimicrobiana em Enterococcus faecalis e Enterococcus faecium isolados de carcaças de frango. Pesquisa Veterinária Brasileira, Seropédica, v. 33, n. 5, p. 575580, 2013.

CARATTOLI, A. Animal reservoirs for extended spectrum betalactamase producers. Clinical Microbiology and Infection, London, v. 14, S1, p. 117-123, 2008.

CARDOSO, A. L. S. P.; TESSARI, E. N. C.; CASTRO, A. G. M.; ZANATTA, G. F. Avaliação da susceptibilidade a antimicrobianos de cepas de Escherichia coli de origem aviária. Arquivo do Instituto Biológico, São Paulo, v. 69, n. 2, p. 1-5, 2002.

CASEllA, T.; RODRIGUEZ, M. M.; TAKAHASH, J. T.; GHIGLIONE, B.; DROPA, M.; ASSUNÇÃO, E.; NOGUEIRA, M. L.; LINCOPAN, N.; GUTKIND, G.; NOGUEIRA, M. C. L. Detection of bla ${ }_{\text {Стх-м }}$ - type genes in complex class 1 integrons carried by Enterobacteriaceae isolated from retail chicken meat in Brazil. International Journal of Food Microbiology, SummitArgo, v. 197, p. 88-91, 2015. 
CHANTZIARAS, I.; BOYEN, F.; CALLENS, B.; DEWULF, J. Correlation between veterinary antimicrobial use and antimicrobial resistance in food-producing animals: a report on seven countries. Journal of Antimicrobial Chemotherapy, Oxford, v. 69, n. 1, p. 827-834, 2013.

CLEMENTE, L.; CORREIA, I.; THEMUDO, P.; NETO, I.; CANIÇA, M.; BERNARDO, F. Antimicrobial susceptibility of Salmonella enterica isolates from healthy breeder and broiler flocks in Portugal. The Veterinary Journal, London, v. 200, n. 2, p. 276$281,2014$.

CLSI - CLINICAL AND LABORATORY STANDARDS INSTITUTE. Performance standards for antimicrobial susceptibility testing. $28^{\text {th }}$ Edition. CLSI Document M100-s28. Wayne: CLSI, 2018.

COSTA, M. L. R Resistência a antibióticos, fatores de virulência e grupos filogenéticos em Escherichia coli produtora de $\beta$-lactamases de amplo espectro de frangos para consumo. 2011. 130 f. Dissertação (Mestrado em Segurança Alimentar) Universidade de Trás-os-Montes e Alto Douro, Vila Real. 2011.

CUNHA, M. P. V.; MENÃO, M. C.; FERREIRA, A. J. P.; KNÖBL, T. A similaridade genética de Escherichia coli patogênica para as aves (APEC) com estirpes humanas e a resistência antimicrobiana justificam a preocupação sanitária em relação aos produtos de origem aviária? Revista de Educação Continuada em Medicina Veterinária e Zootecnia do CRMV-SP, São Paulo, v. 11, n. 1, p. 24-33, 2013.

DIERIKX, C. M.; VAN DER GOOT, J. A.; SMITH, H. E.; KANT, A.; MEVIUS, D. J. Presence of ESBL/AmpC-producing Escherichia coli in the broiler production pyramid: a descriptive study. Plos One, Cambridge, v. 8, n. 1, e79005, 2013.

DUARTE, D. A. M.; RIBEIRO, A. R.; VASCONCELOS, A. M. M.; SANTOS, S. B.; SILVA, J. V. D.; ANDRADE, P. L. A. D.; FALCÃO, L. S. P. D. C. Occurrence of Salmonella spp. in broiler chicken carcasses and their susceptibility to antimicrobial agents. Brazilian Journal Microbiology, São Paulo, v. 40, n. 3, p. 569573, 2009.

EUCAST. European Committee on Antimicrobial Susceptibility Testing. Eucast Expert Rules version 3.1. Intrinsic resistance and exceptional phenotypes tables. 2016. Disponível em: <http:// www.eucast.org/expert_rules_and_intrinsic_resistance $>$.

EWERS, C.; GROBBEL, M.; STAMM, I.; KOPP, P. A.; DIEHL, I.; SEMMLER, T.; FRUTH, A.; BEUTLICH, J.; GUERRA, B.; WIELER, L. H.; GUENTHER, S. Emergence of human pandemic O25:H4-ST131 CTX-M-15 extended-spectrum beta lactamase producing Escherichia coli among companion animals. Journal of Antimicrobial Chemotherapy, Oxford, v. 65, p. 1-10, 2010.

FERNANDES, S. A.; CAMARGO, C. H.; FRANCISCO, G. R.; BUENO, M. F. C.; GARCIA, D. O.; DOI, Y.; CASAS, M. R. T. Prevalence of extended-spectrum $\beta$-lactamases CTX-M- 8 and CTXM-2-producing Salmonella serotypes from clinical and nonhuman isolates in Brazil. Microbial Drug Resistance, Larchmont, v. 0, n. 0, p.1-10, 2016.

FERREIRA, J. C.; PENHA FILHO, R. A.; ANDRADE, L. N.; BERCHIERI JÚNIOR, A.; DARINI, A. L. Detection of chromosomal bla (CTX-M-2) in diverse Escherichia coli isolates from healthy broiler chickens. Clinical Microbiology and Infection, London, v. 20, n. 10, p. 623-626, 2014.
FRACALANZZA, S. A. P.; SCHEIDEGGER, E. M. D.; SANTOS, P. F. D.; LEITE, P. C.; TEIXEIRA, L. M. Antimicrobial resistance profiles of enterococci isolated from poultry meat and pasteurized milk in Rio de Janeiro, Brazil. Memórias do Instituto Oswaldo Cruz, Rio de Janeiro, v. 102, n. 7, p. 853-859, 2007.

GELINSKI, J. M. L. N.; BOMBASSARO, A.; BARATTO, C. M.; VICENTE, V. A. Resistance to extended-spectrum $\beta$-Lactamases in Salmonella from a broiler supply chain. International Journal of Environmental Research and Public Health, Basel, v. 11, n. 11, p. 11718-11726, 2014.

GINNS, C. A.; BROWNING, G. F.; BENHAM, M. L.; ANDERSON, G. A.; WHITHEAR, K. G. Antimicrobial resistance and epidemiology of Escherichia coli in broiler breeder chickens. Avian Pathology, London, v. 25, n. 3, p. 591-605, 1996.

GIRLICH，D.; POIREL，L.; CARATTOLI，A.; KEMPF, I.; LARTIGUE, M. F.; BERTINI, A.; NORDMANN, P. Extendedspectrum beta-lactamase CTX-M-1 in Escherichia coli isolates from healthy poultry in France. Applied and Environmental Microbiology, Washington, v. 73, n.14, p. 4681-4685, 2007.

KAPER, J. B.; NATARO, J. P.; MOBLEY, H. L. Pathogenic Escherichia coli. Nature Reviews Microbiology, London, v. 2, n. 2, p. 123-140, 2004.

KASZANYITZKY, E. J.; TENK, M.; GHIDAN, A.; FEHERVARI, G. Y.; PAPP, M. Antimicrobial susceptibility of enterococci straisisolater from slaughteranimals on the data of Hungarian resistance monitorin g system from 2001 to 2004. International Journal of Food Microbiology, Summit-Argo, v. 115, p. 119-123, 2007.

KOGA, V. L.; RODRIGUES, G. R.; SCANDORIEIRO, S.; VESPERO, E. C.; OBA, A.; DE BRITO, B. G.; DE BRITO, K. C. T.; NAKAZATO, G; KOBAYASHI, K. T. Evaluation of the antibiotic resistance and virulence of Escherichia coli strains isolated from chicken carcasses in 2007 and 2013 from Paraná, Brazil. Foodborne Pathogens and Diseases, New York, v. 12, n. 6, p. 1888, 2015.

LIM, J. S.; CHOI, D. S.; KIM, Y. J.; CHON, J. W.; KIM, H. S.; PARK, H. J.; MOON, J. S.; WEE, S. H.; SEO, K. H. Characterization of Escherichia coli- Producing Extended-Spectrum beta-lactamase (ESBL) isolated from chicken slaughterhouses in South Korea. Foodborne Pathogens and Diseases, New York, v. 12, n. 9, 2015.

MINARINI, L. A. R.; GALES, A. C.; PALAZZO, I. C.; DARINI, A. L. C. Prevalence of community-occurring extended spectrum beta lactamase producing Enterobacteriaceae in Brazil. Current Microbiology, New York, v. 54, p. 335-341, 2007.

MION, L.; COLLA, F. L.; CISCO, I. C.; WEBBER, B.; DIEDRIH, L. N.; PILOTTO, F.; RODRIGUES, L. B.; NASCIMENTO, V. P.; SANTOS, L. R. Perfil de resistência a antimicrobianos por Salmonella Heidelberg isoladas de abatedouro avícola em 2005 e 2009. Acta Scientiae Veterinariae, Porto Alegre, v. 42, p. 1197, 2014.

MOULIN-SCHOULER, M.; RÉPÉRANT, M.; LAURENT, S.; BRÉE, A.; MIGNON-GRASTEAU, S.; GERMON, P.; RASSCHAERT, D.; SCHOULER, C. Extraintestinal pathogenic Escherichia coli strains of avian and human origin: link between phylogenetic groups and common virulence patters. Journal of Clinical Microbiology, Washington, v. 45, p. 3366-3376, 2007. 
PASQUALI, F.; LUCCHI, A.; BRAGGIO, S.; GIOVANARDI, D.; FRANCHINI, A.; STONFER, M.; MANFREDA, G. Genetic diversity of Escherichia coli isolates of animal and environmental origins from an integrated poultry production chain. Veterinary Microbiology, Geneva, v. 178, n. 3-4, p. 230-237, 2015.

RIBEIRO, A. R.; KELLERMANN, A.; SANTOS, L. R.; NASCIMENTO, V. P. D. Resistência antimicrobiana em Salmonella enteritidis isoladas de amostras clínicas e ambientais de frangos de corte e matrizes pesadas. Arquivo Brasileiro de Medicina Veterinária e Zootecnia, Belo Horizonte, v. 60, n. 5, p. 1259-1262, 2008.

SANTOS, L. L.; MOURA, R. A.; RAMIRES, P. A.; CASTRO, A. P. LINCOPAN, N. Current status of extended-spectrum betalactamase (ESBL)-producing Enterobacteriaceae in animals. In: MÉNDEZ-VILAS, A. (Ed.). Microbial pathogens and strategies for combating them: science, technology and education. Badajoz: Formatex Research Center, 2013. p. 1600-1607.

SILVA, K. C.; LINCOPAN, N. Epidemiologia das betalactamases de espectro estendido no Brasil: impacto clínico e implicações para o agronegócio. Jornal Brasileiro de Patologia e Medicina Laboratorial, Rio de Janeiro, v. 48, n. 2, p. 91-99, 2012.

SWEENEY, M. T.; LUBBERS, B. V.; SCHWARZ, S.; WATTS, J. L. Applying definitions for multidrug resistance, extensive drug resistance and pandrug resistance to clinically significant livestock and companion animal bacterial pathogens. Journal of Antimicrobial Chemotherapy, London, v. 73, n. 6, p. 1460-1463, 2018 .
TIVENDALE, K. A.; ALLEN, J. L.; GINNSS, C. A.; CRABB, B. S.; BROWNING, G. F. Association of iss and iucA, but not tsh, with plasmid-mediated virulence of avian pathogenic Escherichia coli. Infection and Immunity, Washington, v. 72, p. 6554-6560, 2004.

TROTT, D. Beta-lactam resistance in gram-negative pathogens isolated from animals. Current Pharmaceutical Design, Xarja, v. 19, n. 2, p. 239-249, 2013.

VAN DEN BOGAARD, A.; STOBBERINGH, E. E. Epidemiology of resistance to antibiotics: links between animals and humans. International Journal of Antimicrobial Agents, v. 14, p. $327-$ 335,2000

ZIECH, R. E.; LAMPUGNANI, C.; PERIN, A. P.; SERENO, M. J.; SFACIOTTE, R. A. P.; VIANA, C.; SOARES, V. M.; PINTO, J. P. A. N.; BERSOT, L. S. Multidrug resistance and ESBL-producing Salmonella spp. isolated from broiler processing plants. Brazilian Journal of Microbiology, São Paulo, v. 47, p. 191-195, 2016.

ZOU, L. K.; WANG, H. N.; ZENG, B.; LI, J. N.; LI, X. T.; ZHANG, A. Y.; ZHOU, Y. S.; YANG, X.; XU, C. W.; XIA, Q. Q. Erythromycin resistence and virulence genes in Enterococcus faecalis from swine in China. New Microbiologica, Bologna, v. 34, p. 73-80, 2011. 